УДК 331.5

JEL Clasification: E24, J24, J31

Blyzniuk V.V., PhD. (Economics), senior research fellow, department of social economic problems of labour, Associate Professor, Institute for Economics and Forecasting, Ukrainian National Academy of Sciences, 26, Panasa Myrnoho Str., Kyiv,01011,Ukraine, e-mail: vikosa72@gmail.com

\title{
EFFICIENCY OF USING LABOR IN INTEGRATION COORDINATES: EXPERIENCE OF NEIGHBORING COUNTRIES
}

\begin{abstract}
Relevant is the research of features of market relations formation and development in labour sphere in post-Soviet countries that chose the same Euro-integration path of development with Ukraine. Author provided trend analysis of the competitiveness index and sub-indices in selected countries. By identifying main problems and bottlenecks in the functioning of the selected countries' labour market, we have established common and unique characteristics and, consequently, possible ways to mitigate the significant social risks. Most acute among them are problem of inefficient employment, large-scale prevalence of informal employment, and inadequate system of labour compensation. Comparative analysis shows that for neighbouring countries that are not EU members (Ukraine and Moldova), a characteristic phenomenon is a significant and unjustified differentiation of wages and the incidence of illegal practices in the workplace. In addition to purely economic factors and the almost complete absence of the use of fiscal instruments, which could stimulate the use of the labour services in the economy's formal sector, the weak control function of the respective bodies in these countries should be highlighted. Particularly acute problem of use of informal payments appears to be for Ukraine, which complicates the problem of social and labour sphere. The author used the following methods: statistical, analogy, comparison. Proposed are the measures for the approximation of the minimal wage up to the European standards, reduction of informal employment, and improvement of the social protection system of the unemployed. It is proved that the regulation of the minimum wage, as the most essential regulator of the labour market, has both positive and negative characteristics and consequences for the social and labour sphere. For the comparative analysis of regulatory impacts of the minimum wage Moldova and Ukraine were chosen. Author has studied the peculiarities of structural changes of employment in the neighbouring countries. This allowed validating the change in the sectoral ratios of employment in Ukraine, which is caused not only by economic factors, but also by the integration and disintegration processes, and it explains the phenomenon of deindustrialization and deagrarization of labour in Ukraine.
\end{abstract}

Keywords: employment, informal employment, nominal wages, sectoral wage differentiation, labor productivity, minimum wage, subsistence minimum of an able-bodied person, unemployment rate, unemployment benefit.

For the Republic of Moldova and Ukraine, the recent quarter-century has been marked by huge social and economic transformations, while the directions of the changes in two countries are different. The collapse of the Soviet era and the emergence of market-based management took place against the backdrop of impoverishment of the majority of population and deepening property differentiation. There was a large-scale destruction of infrastructure, the redistribution of property, formation of private capital with a simultaneous multiple decline in output, especially in industry, rising unemployment and a drop in real incomes.

(C) Близнюк B.B., 2017

ISSN 1681-116X. Український соціум, 2017, № 4 (63): 99-113 
Blyzniuk V.V.

Either neighboring country experienced the above processes in different ways, because initially they had different potentials, and initially they chose different market transition strategies. For Moldova, active use of shock tools and rapid de-industrialization were characteristic. Ukraine, on the contrary, chose a gradual, slow transition to a market economy based on the goal of preserving and developing the existing industrial potential. Either country, in different historical periods has experienced a multi-vector political and economic influence of Russia. To date, both countries are facing a loss of part of their territories, and civil confrontation.

All of the above historical and economic aspects, as well as the revival of globalization, have left their imprint on social and labor relations and labor market in both countries. Taking into account the European orientation of either country, we analyze the current state of labor market, and identify commonalities and differences in the transformation of labor markets in the Republic of Moldova and Ukraine. At the same time, we consider specific of labor markets in the neighboring countries, such as Romania and Poland, which have satisfied their geopolitical claims through membership in the European Union.

Labor markets in Moldova and Ukraine. Globalization that is changing the world economy and affecting values creates various challenges to the labor markets in different countries. The global transformation of social and labor relations and the principles of government social policy are manifested in the crisis phenomena of "social state", which means social equality and development of the middle class in the developed countries. At the same time, the emerging markets are looking for a compromise between a socially satisfied and efficient worker and commercialization of the welfare state. Those are the external determinants that define the development of labor markets and social and labor spheres in Moldova and Ukraine.

In this context, in either country, statements about the need to create an innovative model of economic development rarely go beyond slogans, so both economies are characterized by various non-concerted tendencies with the predominance of raw material based patterns that minimize the involvement of intellectual resource and human capital. Analysis of global competitiveness indicators [1] shows a worsening situation in Ukraine, Moldova and Romania, which is primarily due to the rampant corruption (the importance of this factor for Moldova - 20,6, Ukraine - 14,0), inaccessibility of financial resources (Romania - 16,6), tax regulation (Poland - 20,6), excessively rigid labor legislation (Poland-14,1), and shortage of skilled labor (Romania - 10,4). As for the component indicator of competitiveness, in the context of the development of human capital (in terms of efficiency of the labor market), the situation in Ukraine seems better (73rd place out of 139) due to such components as labor compensation and productivity (42nd place), and labor costs (50th place). For Poland, Moldova and Romania, the most important determinant of this sub-index is the flexibility of wages (29th, 37th and 31st places respectively) while Moldova occupies a very low place (100th) in terms of labor costs (Poland occupies the 80th place, and Romania - the 6th place).

Statistics show that the growth of wages in Poland since the beginning of the 2000s has been rather insignificant (Fig. 1). Financial crisis and accession to the European Union have 
affected the dynamics of wages in Romania (their growth is insignificant and inflation is on decline), while in other post-Soviet countries, inflation is much higher.
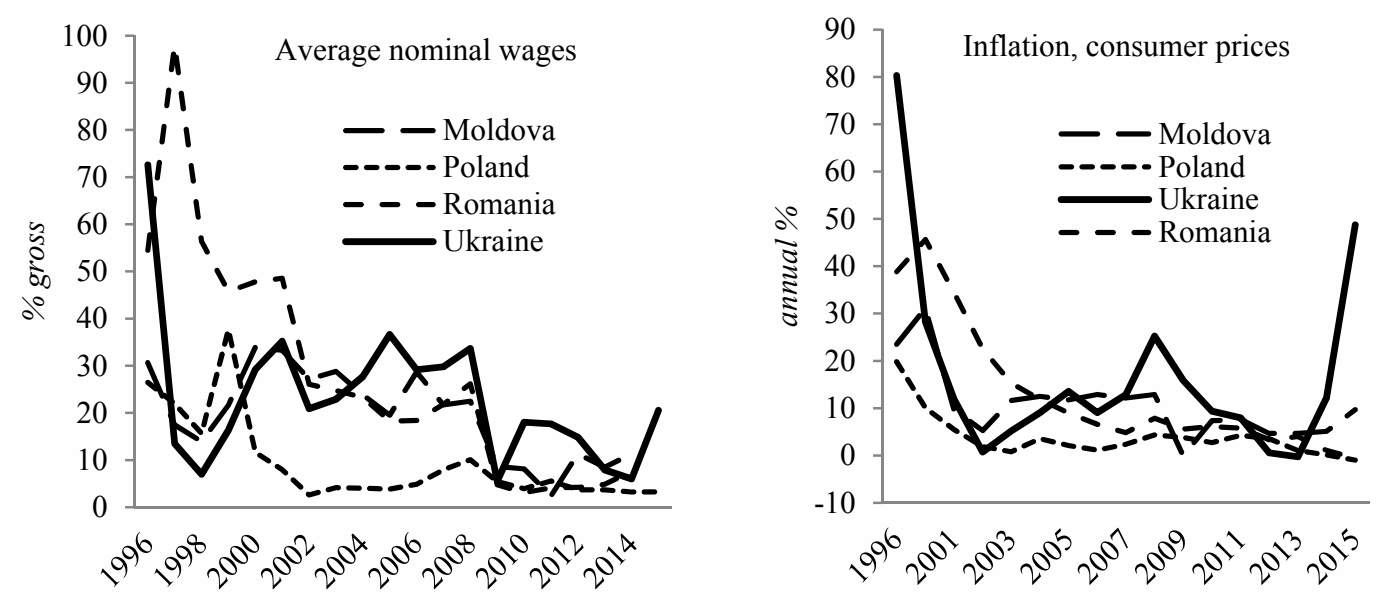

Fig. 1. Dynamics of nominal monthly wages and inflation in four countries, 1996-2015

Source: World Development Indicators. URL: http://databank.worldbank.org/Data/ reports.aspx?source=world-development-indicators

Compared to those countries, the dynamics of nominal wages in Ukraine shows some positive trends, except for the period of the global financial crisis, when the growth of minimum standards and wages in the public sector was administratively frozen, as well as the growth of pay rate of the first category of the Unified Tariff Grid in the budget sector. In the Republic of Moldova in recent years, the nominal wage has been demonstrating a steady growth. Thus, in 2015 an employee's average monthly salary was 4538,4 lei, which is by $11 \%$ more than in 2014.

However, due to the devaluation of national currency, nominal wages in dollar terms decreased from $\$ 291,3$ in 2014 to $\$ 241,2$ in 2015 , that is, by 50,1 dollars, or by $17,2 \%$. In Ukraine, the rate of reduction in the nominal wage was even more significant, from \$ 293 in 2014 to $\$ 193$ in 2015 , i.e. by $\$ 100$, or by $34,1 \%$ [2]. As a result, for the first time in recent twenty years, the nominal wage in dollar terms in Moldova exceeded its level in Ukraine.

An important factor characterizing the wage system is the degree of wage differentiation. Among a number of indicators used to assess inequality at the national level are the upper, median and lower decile wage factors. Recent global trends in wage size and share, as stated in the ILO "Global Wage Report 2016/17: Wage inequality in the workplace" [3], should be viewed in the context of deepening wage inequalities arising from the rapid growth of high wages in the upper segment and wage stagnation in the middle and lower segments of the income distribution scale.

Increased inequality is primarily due to the "upward gap" of the most highly paid workers from the majority of workers, as well as the "downward gap", i.e. increase in the 
difference between workers with a median wage and low-paid ones. The signs of sectoral differentiation in labor remuneration in Ukrainian economic sectors have been traditional for many recent years and are significant in comparison with European figures [4].

Thus, in Ukraine, there is a significant deviation towards increase from the average salary in financial and insurance activities, in industry (at the expense of wages in the aviation industry), and in the field of information and telecommunications. Significantly lower than country average are the wages in education and health care, that is, exactly in those areas where reproduction and accumulation of human capital occurs (Fig. 2). A similar situation develops in Moldova. In 2016, while average monthly wage per one employee in information services and communications was 2,1 times the average in the economy, and in finances and insurance - 1,8 times, the average monthly salary per one worker in the field of art, entertainment and leisure services was only $66,6 \%$ of economic average, and in agriculture, forestry and fisheries $-66 \%[5]$.

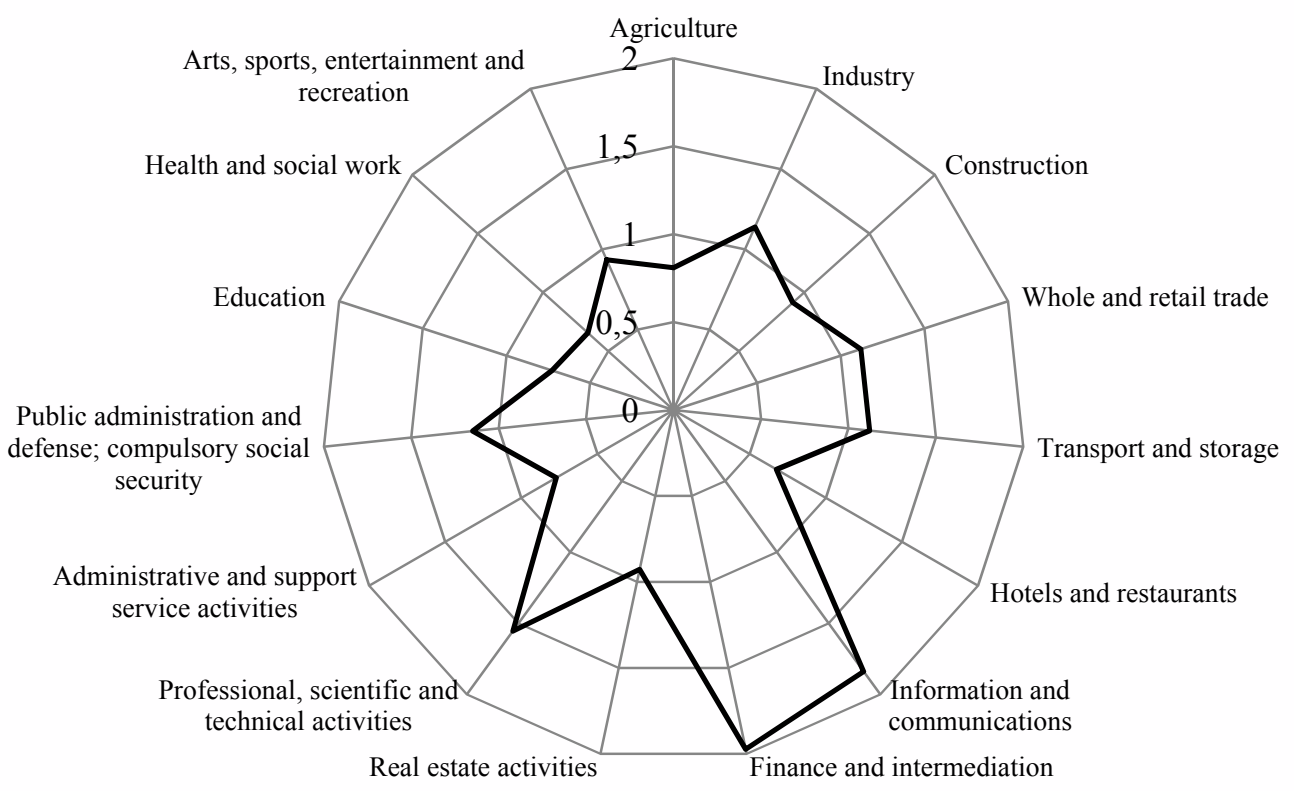

Fig. 2. Sectoral wage differentiation in Ukraine, 2016

Source: Official site of the State Statistics Service of Ukraine. URL: http://www.ukrstat.gov.ua/

In January 2017, hoping to decrease the shadow share of the labor market, Ukraine significantly and sharply raised minimum wage (from $1600 \mathrm{UAH}$ up to $3200 \mathrm{UAH}$ ). However, in the budgetary sector, the size of the first tariff category was again frozen at $1,600 \mathrm{UAH}$, and changes were made in the economic content of minimum wage, which is now not a measure of the cost of simple unskilled labor, but only the minimum payment for a certain period of time. 
Expected implications for the budgetary sector include, first of all, payment equalization due to the reduction of differentiation, that is, from 1 to 11 tariff categories, workers receive a minimum wage (for reference, teachers of all specialties can have a grade from 10 to 12 , while the 1 st category includes janitors, cleaning personnel etc.).

The Republic of Moldova maintains a low minimum wage. The problem is exacerbated by the existence of several levels of minimum wages:

$A$. The minimum wage for general use. It has a very limited scope and is used only to pay to certain categories of workers. For example, it is used to establish monthly remuneration of government representatives in the management bodies of state-owned enterprises and jointstock companies, as well as enterprises with a predominance of state capital.

In 2001-2015, the minimum wage increased from 100 to 1000 lei per month, i.e. tenfold. The ratio of minimum wage to subsistence minimum of an able-bodied person indicates that, during 2001-2015, the amount of minimum wage covered the value of subsistence minimum by only $14-58 \%$ [6]. A similar trend is typical for the ratio between minimum and average wages. In 2015, the value of this ratio, which in the literature is referred to as Keitz index, was $21,7 \%$.

At present, the Republic of Moldova in terms of minimum wages is inferior not only to developed countries, but also to many CIS countries. As of January 1, 2016, Moldavian minimum wage in dollar terms was $\$ 51$, while in Belarus it was 124 dollars (2,4timeshigher), in Armenia - 114 dollars (2,2 times), in Russia - \$86 (1,7 times), in Kazakhstan - \$67 (1,3 times), and in Ukraine - \$57 (1,1 times). Only In Tajikistan and Kyrgyzstan (\$ 36 and \$13 respectively), minimum wage was lower than in Moldova [2].

$B$. The guaranteed minimum wage in the real sector represents the minimum mandatory state-guaranteed wage, for work performed by an employee in the real sector. In Moldova, from May 1, 2015, the guaranteed minimum wage in the real sector was 1900 lei, and since 1 May 2016, it has been 2100 lei per month. This made it exceed the level of the subsistence minimum of an able-bodied person by 3,1\% in 2015 and by $9,0 \%$ in 2016 . However, these positive changes are clearly insufficient. According to the European Social Charter, the minimum wage should be set by the state at a level no less than 2,5 times the subsistence minimum. Thus, to achieve the recommended European level, a significant increase in the minimum wage is necessary.

Due to the extremely low minimum wage in Moldova and Ukraine, a significant stratum of the poor is preserved in both countries. In 2015, the proportion of employees who had wages below the minimum wage was $0,2 \%$ in Moldova and $4,4 \%$ in Ukraine (Table 1). For Ukraine, a positive fact is a decrease in the proportion of workers with wages below the minimum wage, from $5,2 \%$ in 2012 to $4,4 \%$ in 2015 , i.e. by 0,8 percentage points. Moldova and Ukraine are characterized by the phenomenon of the working poor, when the availability of work does not guarantee the workers an exit from poverty. In fact, workers living below the poverty line are on the brink of survival. Many of them, trying to earn their living, are forced to work in several places to the detriment of their health.

As noted in the Global Competitiveness Report [1], for Ukraine and Moldova, in general, inefficiency and rigidity of the taxation of labor incomes is common: in term of this indicator, Moldova occupies 109th place, and Ukraine - 124th, for non-professionalism of 
management, the two countries occupy the 115th and 114th places respectively. But, in terms of the representation of women in the labor force, our countries are much ahead of their European neighbors, which however does not always mean a realized ambition, but often is a sheer economic necessity due to the very low living standards.

Table 1

Distribution of workers by the amount of wages in Moldova and Ukraine, \% of total

\begin{tabular}{|c|c|c|c|c|c|}
\hline & \multirow[b]{2}{*}{ Years } & \multirow[b]{2}{*}{ Total workers } & \multicolumn{3}{|c|}{ Distribution of workers } \\
\hline & & & $\begin{array}{c}\text { less than } 1 \\
\text { minimum wage (MW) }\end{array}$ & 1-3 MW & over $3 \mathrm{MW}$ \\
\hline \multirow{2}{*}{ Moldova } & 2012 & 100,0 & 0,1 & 29,6 & 70,3 \\
\hline & 2015 & 100,0 & 0,2 & 42,7 & 57,1 \\
\hline \multirow{2}{*}{ Ukraine } & 2012 & 100,0 & 5,2 & 62,1 & 32,7 \\
\hline & 2015 & 100,0 & 4,4 & 79,5 & 16,1 \\
\hline
\end{tabular}

Source: Global wage report 2016/17: Wage inequality in the workplace International Labour Office. (2016). Geneva: ILO.

The economic constraints on the development of the social and labor spheres of both countries are similar, but the institutional features that have developed are different. Differences and imbalances in the labor sphere, on the one hand, impart dynamism to the processes of the social and labor sphere, and on the other, strengthen the gap and the depth of stratification.

On the one hand, the peculiarities of the social and labor sphere and the presence of structural disproportions of employment represent limits to economic development, and on the other side they are a consequence of the processes of integration and globalization in the world. In this context, a sectoral analysis of employment in Ukraine and Moldova could be indicative. The sectoral structure of employment characterizes civilizational changes in the structure of the economy and the efficiency of economic employment policy in the country, which is manifested in changes in the shares of the primary, secondary and tertiary sectors in the GDP structure.

The long-term dynamics of the world economy testifies to a significant flow of workers from the sphere of agriculture, where almost $80 \%$ of the workforce were employed in the beginning of the industrial age, to the manufacturing industry, and later to the service sector. These tendencies of decrease in the share of those employed in the primary and secondary sectors are also observed in the structure of Ukraine's labor market (Table 2). The quantitative characteristics of the developments in the social and labor sphere of Ukraine and Moldova, namely the growth of the tertiary employment sector from $47,2 \%$ in 2000 up to $60,1 \%$ in 2015 , and from $30,8 \%$ to $39,6 \%$, respectively, could have been interpreted as a civilizational transition to the phase of post-industrial development, if we did not take into account the cause-effect relationships of those changes.

Thus, in contrast to the European countries where such shifts take place within a single economic system, in Ukraine and Moldova structural changes have occurred mainly against the background of the destruction of the old economic system. The existing sectoral differences deepened and aggravated the contradictions inherited from the previous system (being one of them the disparity of the sector structure of the economy) 
and a new restructuring took place as a result of the formation of the new system (changes in the value system, formation of new sectors, and changed demand structure on the domestic and foreign markets).

The sectoral structure of employment in Moldova indicates a high degree of employment insecurity, as the share of agrarian employed remains very high. In 2015, the share of employed in agriculture was $28,4 \%$ and, unlike neighboring countries, tended to increase. Compared to 2010, the share of employed in Moldova's agriculture increased by 0,9 percentage points. This was a direct consequence of the privatization of land and the dominance of small-scale production in the agricultural sector, which is characterized by low added value and productivity. The lowest rates of employment in agriculture are observed in Poland $(11,3 \%)$ and Ukraine $(15,3 \%)$, where the rural residents' work in the agro-holdings has become a common phenomenon (Table 2).

Sectoral changes in the employment structure of developed countries were due to the flow of labor from secondary to tertiary sector as a result of the outstripping growth in labor productivity in industry and a higher income elasticity of demand for services than for goods.

For Ukraine, however, the change in the ratio between sectors is not only due to purely economic factors, but as a result of the processes of integration and disintegration. Disintegration processes were the cause of the de-industrialization. This process, in Ukraine, began as far back as in the late 80 s of the last century with the increase in the level of depreciation of industrial fixed assets, which in 1990 amounted to almost $48,7 \%$ compared to $37,4 \%$ in 1980 . De-industrialization led to the redistribution of national income in favor of agriculture, and further structural changes caused de-agrarization.

Employment distribution in Moldova, Ukraine and neighboring countries, $\%$

Table 2

\begin{tabular}{|c|c|c|c|c|}
\hline \multirow{2}{*}{ Reference area } & \multirow{2}{*}{ Time } & \multicolumn{3}{|c|}{ Employment distribution - ILO estimates and projections } \\
\hline & & Agriculture & Industry & Services \\
\hline \multirow{4}{*}{ Moldova } & 2000 & 36,0 & 33,2 & 30,8 \\
\hline & 2005 & 32,9 & 32,5 & 34,6 \\
\hline & 2010 & 27,5 & 32,2 & 40,3 \\
\hline & 2015 & 28,4 & 31,9 & 39,6 \\
\hline \multirow{4}{*}{ Poland } & 2000 & 18,6 & 31,1 & 50,3 \\
\hline & 2005 & 17,4 & 29,2 & 53,4 \\
\hline & 2010 & 12,8 & 30,1 & 57,1 \\
\hline & 2015 & 11,3 & 30,2 & 58,5 \\
\hline \multirow{4}{*}{ Romania } & 2000 & 45,2 & 25,8 & 29,0 \\
\hline & 2005 & 32,3 & 30,5 & 37,3 \\
\hline & 2010 & 30,1 & 28,6 & 41,3 \\
\hline & 2015 & 26,4 & 29,0 & 44,5 \\
\hline \multirow{4}{*}{ Ukraine } & 2000 & 28,5 & 24,3 & 47,2 \\
\hline & 2005 & 27,9 & 22,7 & 49,4 \\
\hline & 2010 & 20,3 & 25,7 & 54,0 \\
\hline & 2015 & 15,3 & 24,7 & 60,1 \\
\hline
\end{tabular}

Source: World Development Indicators. URL: http://databank.worldbank.org/Data/ reports.aspx?source=world-development-indicators 


\section{Blyzniuk V.V.}

Deindustrialization in Ukraine was manifested not only in the flow of labor to high-tech industries and in the growth of the service sector, but also in the growth of the raw-material sector. New integration ties developed at the expense of the raw materials sector, intermediate products dominated in the structure of exports, and the share of raw materials grew, which, correspondingly, required expanded employment in these sectors.

In developed countries, the growth of the service sector does not occur at the expense of the productive sector, but rather on its basis and at the same time is a determinant of its development at a qualitatively different level. Many service activities are directly related to production, namely $R \& D$, marketing, engineering and consulting services that contribute to the building up and qualitative renovation of material production which not only satisfies the basic needs of the population, but also boosts the level of consumption.

Ukraine, on the contrary, is characterized by a weak development of the secondary sector, due to the poor performance of the construction (compared to general European trends, where construction rapidly became an engine of GDP and employment growth, as well as a stimulus for the development of related sectors).

Post-industrial development itself does not imply a fall or stagnation of industrial output, but rather a moderate growth, while some slowdown of its rate is due to a relative satisfaction of the needs for industrial development. However, these characteristics do not apply to Ukraine, where today there are no grounds for assessing the current level of production as sufficient for solving this country's basic problems. Structural changes in employment depend, first of all, on changes in productivity, which is in turn determined by the level of capital intensity and utilization of production capacities.

At the same time, labor productivity is an aggregate indicator of the use of working time, workers' qualifications, organization of the process of production, and efficiency of the wage systems. In the long run, the dynamics of wages should correspond to the dynamics of productivity. As can be seen from Fig. 3, the dynamics of the recent 15 years indicate a predominant trend of excess of the growth of nominal wage over that of labor productivity in both Moldova and Ukraine. An exception is the period of the global financial and economic crisis, which caused significant losses in both economies. Wage growth in Ukraine has traditionally been higher than in Moldova, except for the period of significant devaluation of Ukraine's national currency which began in 2014.

This trend can also be explained by the restructuring of production costs by reducing the share of material costs in favor of higher labor costs. Violation of macro-proportions in the form of excessive growth of productivity over wages is possible at certain stages of economic development, for example, during the post-crisis recovery of the economy, because then it facilitates the transformation of domestic demand into a source of economic growth, especially during import substitution. Increased domestic demand creates incentives for output growth and is the driving force behind the need for investment and a basis for intensifying labor, and entrepreneurial and creative activities.

However, the existence of such a long-term trend is unacceptable, since it does not promote not only expanded, but even a simple reproduction, and leads to an imbalance between supply and demand. 

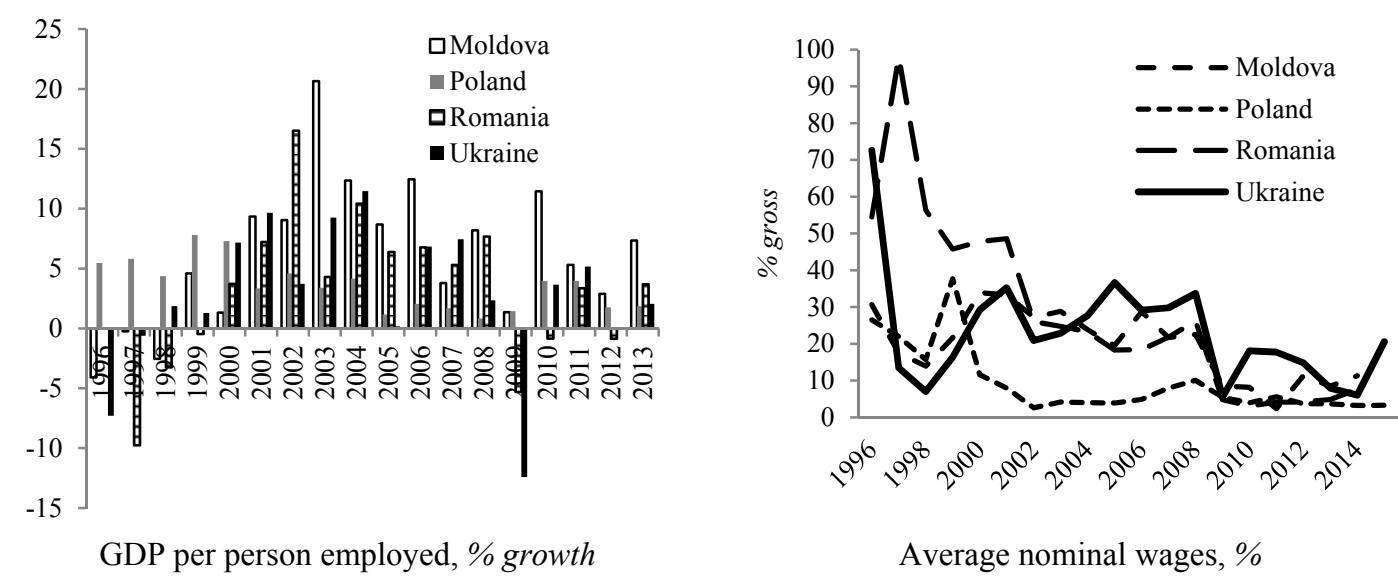

Fig. 3. Growth rates of labor productivity and nominal wage in four countries, 2001-2015

Source: World Development Indicators. URL: http://databank.worldbank.org/Data/ reports.aspx?source=world-development-indicators

The long-term growth of aggregate demand and wages, exceeding productivity growth, only leads to price increase without affecting output growth and unemployment.

Thus, various macroeconomic barriers have determined identified an inefficient and archaic employment structure in both Ukraine and Moldova, characterized by a high share of employment in the inefficient subsidiary farming and a significant share of the primary sector in the economy as a whole. So, the modern structure of employment no longer has signs of an industrial one, but it has not acquired any innovative characteristics either. The development of the economy and the labor market occurred within a regressive pattern with a pronounced reduction and de-skilling of labor, and primitivization of its use.

In Ukraine, the main determinants of the non-optimal employment structure include: maintaining the outdated technological base on a large part of domestic enterprises; prevalence of the raw material component of economic growth; low reaction of the professional structure of labor to structural changes, inadequacy of the professional structure of labor to the needs of employers (when the latter intend to implement technological updating), low level of mobility of the population and hired workers, low and uncompetitive wage levels, and the presence of the working poor, which in turn demotivates effective employment.

Among the indicators of health of the labor market were and are unemployment rates. A comparative assessment of labor markets in Ukraine, Moldova and European countries indicates a certain stability of the post-Soviet markets (Fig. 4).

Poland, which was one of the first to enter the path of European integration, has the highest unemployment rates among the analyzed countries. Compared to the figures significantly exceeding $10 \%$ of economically active population, the unemployment rates of Ukraine and Moldova look more than modest. At the same time, the unemployment rate in Moldova is lower than in Ukraine. 


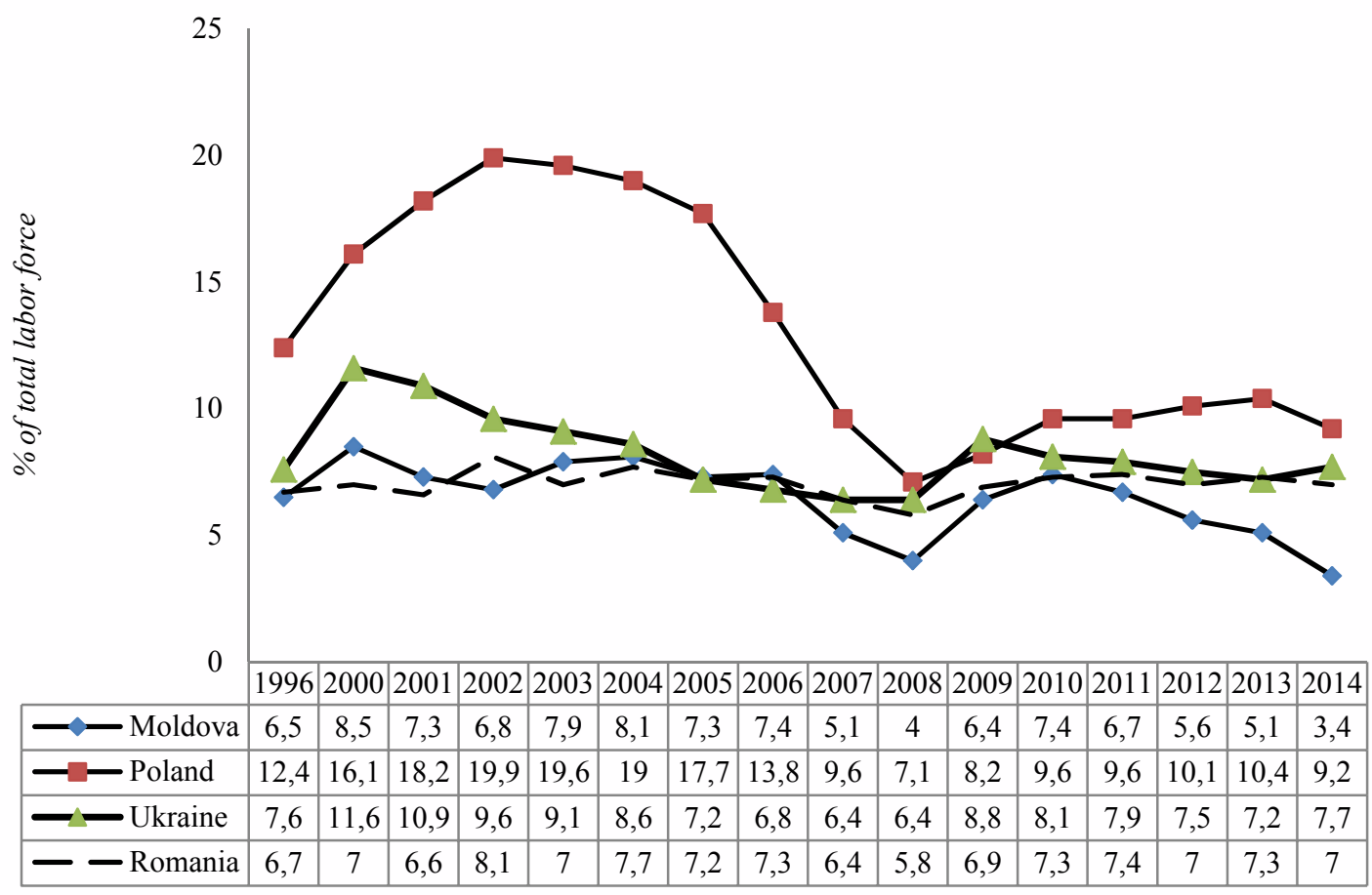

Fig. 4. Unemployment levels (ILO) in Moldova, Ukraine and neighboring countries, $\%$ Source: World Development Indicators. URL: http://databank.worldbank.org/Data/ reports.aspx? source=world-development-indicators

In the Republic of Moldova and Ukraine, there is a system of social protection for persons looking for a job. Those officially recognized as unemployed, according to the law, are paid unemployment benefits. However, in Moldova this legislation is more stringent than in Ukraine [7]. As a result, the number of unemployed having the right to unemployment benefits is essentially limited in Moldova: it is only paid to $8 \%$ of registered unemployed, while in Ukraine the figure is $81 \%$.

In December 2015, the average unemployment benefit (in dollar terms) was $\$ 63$ in Moldova and \$ 60 in Ukraine [5; 8]. Such assistance is clearly insufficient. For example, in Moldova in 2015, the ratio of average unemployment benefit to subsistence minimum of an able-bodied person was only $68,2 \%$, and the ratio to the average monthly salary was $27,2 \%$.

One of the significant challenges for both countries is the so-called hidden unemployment or employment in the informal sector, which serves as a shock absorber of unemployment, because it is in this sector where the least competitive part of the labor force is absorbed during periods of economic decline or stagnation. Unemployment, strengthening social inequality, determines the risks of what is called "social exclusion".

A fairly new concept of social sciences, "exclusion", appeared in France in the sixties, describing individuals thrown to the margins of economic progress due to the widening gap between the prospering ones and the "useless" others [9]. As suggested by 
further studies, exclusion is not the cause of individual failures, shortcomings and passiveness of the individuals, but is a social phenomenon, whose root cause lies in the principles of functioning of the modern society, and which concerns an increasing number of people in the world.

Social exclusion is mainly defined as an exclusion of individuals or social groups from the social structure of society and/or social processes, due to the influence of certain conditions that prevent individuals or groups from playing a significant role in society. Summarizing various concepts and approaches to the essence of social exclusion, it is possible to define the following components: on the one side "excluded" persons, and on the other is the society, which is, for one reason or another, closed for them. Separate components of social exclusion are the causes and circumstances of its emergence and development. One of the reasons is the spread of shadow and informal forms of employment.

For the first time, employment in the informal sector, including the primitive and diverse self-employment of urban slum dwellers in developing countries, was described in the works of K. Hart, in which the author pointed to the heterogeneity of job characteristics in this sector and their concentration in the unregulated market segment [10]. This approach was taken as a basis by international organizations dealing with labor statistics and measurement of employment in the informal sector and consisted in the fact that those involuntarily employed in the informal sector perform primitive, unskilled, underpaid and socially unprotected work. Later, a theoretical justification for the non-overlapping segments of the labor market was extended in the theory of the dual labor market by J. Harris and M. Todaro, which analyzed the migration from villages to cities and the expected wages in different segments. Globalization, together with the changed working conditions and educational level of the workforce made it possible to revise the theory of the informal sector and draw conclusions about its heterogeneity and segmentation [11].

This approach, in our opinion, most fully characterizes the features of employment in the informal sector [12; 13]. Workplaces of the informal sector are not always of the worst quality, workers voluntarily make decisions about participation, and intersectoral wage differences are not always significant, for which reason this sector is often similar to micro-business in developed countries. Legislative protection of employment in the formal sector is not always an advantage for workers, since they can, on the one hand, have different values, for example, flexible working hours, additional earnings, and, on the other, a low level of confidence in the institutions of formal employment.

Recently, informal employment in Ukraine and Moldova has been rapidly expanding, covering a significant number of jobs in the formal and informal sectors of the economy (Fig. 5). The negative consequences of this phenomenon are manifested in limited opportunities for the realization of most social rights provided for by the Constitution and labor legislation; increased risk of unstable employment and income; inefficient use of available labor potential.

According to official statistics, the share of informal employment in either country is quite high and covers more than a quarter (Ukraine) and more than a third (Moldova) of employed population. This shows a significant deformalization of labor relations. Traditionally, informal employment is represented in both countries by workers in agriculture, construction, and services. In Moldova, informal employment mainly includes 
workers engaged in agriculture, hunting, forestry and fishing $(73,2 \%)$, while workers in the construction sector account for $10,4 \%$ of total [14].

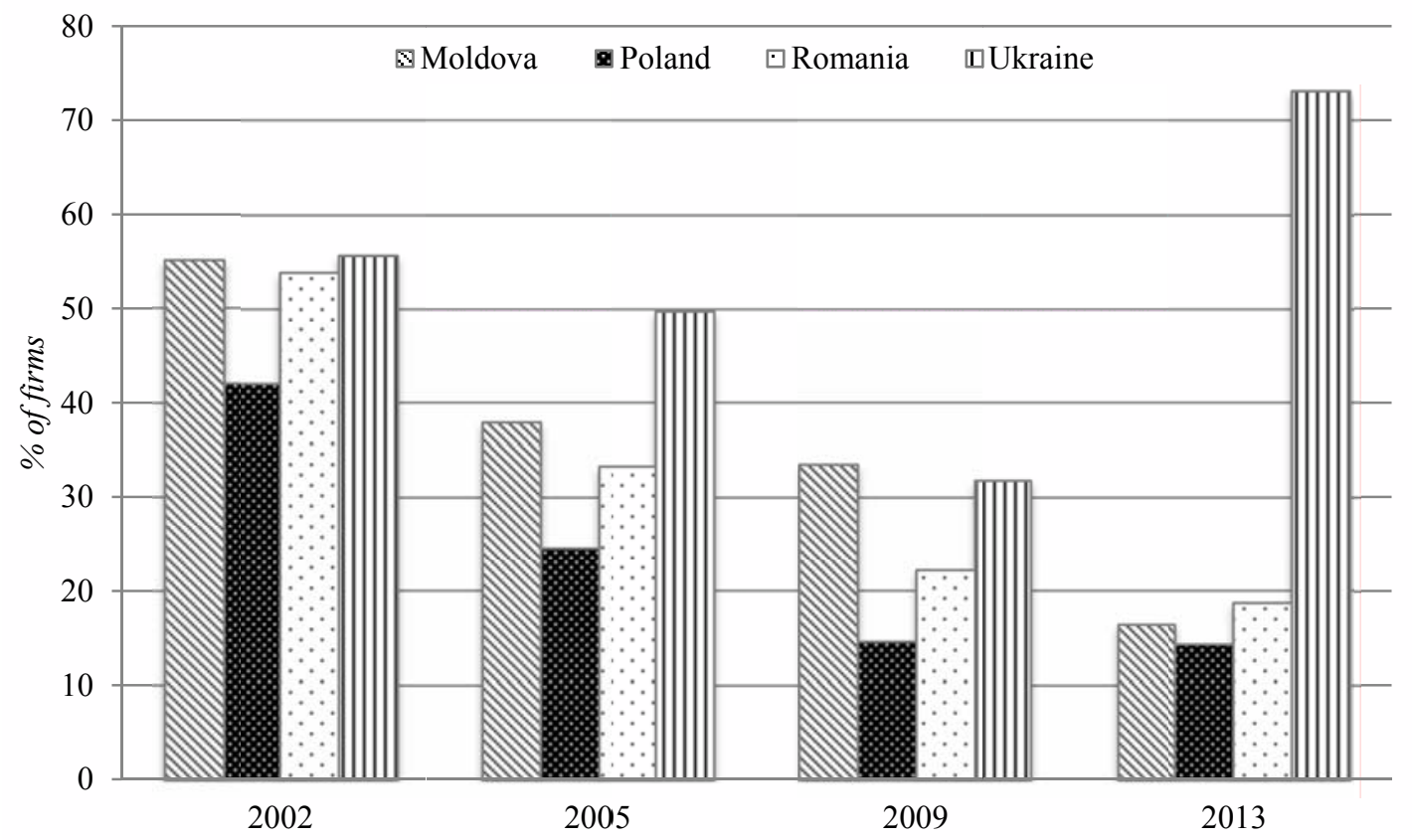

Fig. 5. Informal payments to public officials

Source: World Development Indicators. URL: http://databank.worldbank.org/Data/ reports.aspx?source=world-development-indicators

Among the informal workers, the share of the youngest and oldest age groups is higher than among those formally employed. In Moldova, in the structure of the informal employment, the share of people aged 15-24 years is 1,3 times higher than among the formally employed, and the share of workers at the age of 65 and over is 3,1 times higher. And, conversely, the proportion of middle-aged people among informal workers is lower than among the formally employed [14].

The spread of informal employment among young people is explained by the strategy of smooth transition from study to work, while people of pension age are engaged in this sector mainly due to low pensions, which cause a high level of poverty among the elderly and force them search for informal means of subsistence.

The desire to continue working makes older people agree to informal employment and to jobs unattractive for their younger counterparts.

Describing the employment in the informal sector, it is necessary to emphasize the lack of legal regulation of social and labor relations and social protection of employees. At the 
same time, informal employment creates a reserve of labor force, thus satisfying the dynamic needs of the real sector.

Informal employment, with the significantly rigid legislation [15], allows to expand opportunities when a person chooses a comfortable work schedule, depending on family and life circumstances, and becomes a source of income for part of the workforce. In crisis conditions, the role of the informal sector as a shock absorber of the economic recession is unquestionable. But it is necessary to understand that the prevalence of this form of employment practically excludes innovative development of the country.

Conclusions. The conducted research has shown that in the sphere of employment, the most acute problems in the Republic of Moldova and Ukraine are the widespread informal employment, the shortcomings in the wage system and unemployment.

1. Based on international experience, we propose the following measures to reduce informal employment in Moldova and Ukraine:

- preventive measures to simplify procedures, as well as reduce costs and restrictions that impede the creation and development of business;

- sanctions aimed at strengthening the oversight on and applying appropriate sanctions against those who benefit from hidden/shadow work;

- raising public awareness of the negative effects of informal employment.

2. In the area of labor remuneration, the following measures should be taken:

a) for the Republic of Moldova:

- to ensure the establishment of a minimum wage at the subsistence level of an able-bodied person;

- to develop measures for transition to the definition of a minimum wage in accordance with the principles of the European Social Charter (minimum wage cannot be less than $60 \%$ of average);

б) for the Republic of Moldova and Ukraine:

- to provide for the increase in the amount of the 1st category of labor remuneration for workers in the budget funded sector to the level of the subsistence minimum of an able-bodied person;

- to use as a reference point the tariff-wage proportion of no less than $50 \%$ as the optimal for the current state of the economy;

- in order to ensure the timely payment of wages, it is necessary to additionally envisage indexing of the amount of delayed wages by the employer in the amount of inflation that has occurred since the moment of the emergence of the wage debt;

- to develop and implement measures to bring closer the levels of remuneration for women and men (measures to promote women's carrier advancement, to upgrade their skills, to eliminate unjustified reduction of women's pay rate in comparison with men in equivalent jobs).

3. In order to reduce unemployment, it is necessary:

- to encourage the companies' activities on creating new jobs, first of all, in terms of tax privileges to the companies saving and creating economically expedient jobs;

- to improve the mechanism of organizing paid public works in terms of increasing their social status, taking into account the region's needs in the development of social 
Blyzniuk V.V.

infrastructure, implementation of national projects and financial support for unemployed citizens;

- promote youth employment through: professional advice and psychological support; vocational training; employment on permanent job; promoting business activities.

\section{References}

1. The global competitiveness report 2016-2017. World Economic Forum. URL: www.weforum.org [in English]

2. On status of salaries in the independent States of the region in 2015. (2016). The General Confederation of Trade Unions. Moscow. URL: http://vkp.ru/docs/47.html [in Russian]

3. Global wage report 2016/17: Wage inequality in the workplace International Labour Office. (2016). Geneva: ILO. URL: http://www.ilo.org/wcmsp5/groups/public/---dgreports/---dcomm/--publ/documents/ publication/wcms_537846.pdf [in English]

4. Blyzniuk, V.V. (2016). Ukrainian labor market: historical challenges and new tasks. Ukr. socium Ukrainian society, 3, 58-71. URL: http://nbuv.gov.ua/UJRN/Usoc_2016_3_7 [in Ukrainian]

5. Statistical year book of the re public of Moldova. (2016). Chisinau: National Bureau of Statistics of the Republic of Moldova [in English]

6. Rojco, A. (2016). Justification of minimal quantum of wage in the Republic of Moldova. Economie şi Sociologie - Economy and Sociology, INCE, 3, 63-68 [in English]

7. Rojco, A., Ivanov, S. (2016). Perfecționarea si stemului de protecție socială a Nomerilor în Republica Moldova. Creşterea economica in condițiile globalizării - Economic growth in conditions of globalization, INCE, 2, 248-252 [in Romanian]

8. Official site of the State Statistics Service of Ukraine. URL: http://www.ukrstat.gov.ua/ [in English]

9. Pogam, S. (1999). Exclusion: social instrumentalization and study results. Zhurnal sotsiologii $i$ sotsialnoi antropologii. T. II. Spetsial'nyi vypusk: Sovremennaya frantsuzskaya sotsiologiya - Journal of sociology and social anthropology. Vol. II. Special issue: Modern French Sociology, 140-156 [in Russian]

10. Hart, K. (1973). Informal income opportunities and urban employment in Ghana. Journal of Modern African Studies, 11, 61-89 [in English]

11. Fields, G.S. (1990). Labour market modelling and the urban informal sector: Theory and evidence. In D. Turnham, B. Salomé, A. Schwarz (Eds.), The informal sector revisited (pp. 49-69). Paris: Organisation for Economic Cooperation and Development [in English]

12. Bechmann, U., Radeke, J. (2014, June). Measures to reduce informal employment in Moldova. German Economic Team Moldova. Policy Paper [PP/04/2014]. Berlin, Chisinau: German Economic Team Moldova. URL: https:/get-moldau.de/download/policypapers/2014/ PP_04_2014_en.pdf [in English]

13. The Scope and Main Characteristics of Informal Employment in Ukraine, Technical Note for the Government of Ukraine by the World Bank. (2011). World Bank. URL: http://siteresources.worldbank.org/ UKRAINEINUKRAINIANEXTN/Resources/4556801310372404373/InformalEmploymentinUkraineEng. pdf [in English]

14. Rozhko, A., Stremenovskaia, Z. (2016). Informal employment in the Republic of Moldova: the scope and measures for its reduction. Creşterea economica in condițiile globalizării - Economic growth in conditions of globalization, INCE, 2, 236-241 [in Russian]

15. Yuruk, Ya.I. (2015). Evaluation and comparative analysis of the stiffness of the Ukrainian legislation on employment protection. Ekonomika ì prognozuvannâ - Economy and forecasting, 1, 23-39. URL: http://nbuv.gov.ua/UJRN/econprog_2015_1_4 [in Ukrainian]

Received on 15.11.17 and updated on 11.12.17 
Близнюк В.В., канд. екон. наук, старший науковий співробітник відділу соціально-економічних проблем праці ДУ “Інститут економіки та прогнозування НАН України”, вул. П. Мирного, 26, Київ, 01011, Україна, e-mail: vikosa72@gmail.com

\section{ЕФЕКТИВНІСТЬ ВИКОРИСТАННЯ РОБОЧОЇ СИЛИ В ІНТЕГРАЦЙНИХ КООРДИНАТАХ: ДОСВІД СУСІДНІХ КРАЇН}

Актуальним є дослідження особливостей становлення та розвитку ринкових відносин в трудовій сфері в краӥнах, які пройшли однаковий шлях з Україною. Проаналізовано динаміку індексу та субіндексів конкурентоспроможності в обраних краӥнах, ще дозволило виявити спільні та унікальні характеристики $i$, відповідно, можливі шляхи пом'якшення суттєвих сочіальних ризиків, визначити проблемні елементи функиіонування ринку праці. Обтрунтовано, що найгострішими є проблема неефективної зайнятості та деформалізація трудових відносин. Так, для Украӥни та Молдови характерними є суттєва, необтрунтована диференціація оплати праці та поширеність неправових практик у трудовій сфері. Глибокий аналіз дозволив обтрунтувати, щзо зміна секторальних співвідночень зайнятості в Украӥні зумовлена не тільки економічними факторами, але й інтеграчійними та дезінтеграційними процесами, щ̧о пояснює явища деіндустріалізації та дезаграрізації праці.

Ключові слова: зайнятість, неформальна зайнятість, номінальна заробітна плата, галузева диференціація заробітної плати, продуктивність праці, мінімальна заробітна плата, прожитковий мінімум працездатної людини, рівень безробіття, допомога по безробіттю.

Близнюк B.В., канд. экон. наук, старший научный сотрудник отдела социально-экономических проблем труда ГУ “Институт экономики и прогнозирования НАН Украины”, ул. П. Мирного, 26, Киев, 01011, Украина, e-mail: vikosa72@gmail.com

\section{ЭФФЕКТИВНОСТЬ ИСПОЛЬЗОВАНИЯ РАБОЧЕЙ СИЛЫ В ИНТЕГРАЦИОННЫХ КООРДИНАТАХ: ОПЫТ СОСЕДНИХ СТРАН}

Актуальным является исследование особенностей становления и развития рыночных отношений в трудовой сфере в странах, прошедших тот же путь, что и Украина. Проанализирована динамика индекса и субиндексов конкурентоспособности в избранных странах, что позволило выявить общие и уникальные характеристики $u$, соответственно, возможные пути смягчения существенных соииальных рисков, определить проблемные элементы функционирования рынка труда. Обосновано, что наиболее острыми являются проблема неэффективной занятости $u$ деформализаџия трудовых отночений. Так, для Украины и Молдовы характерны существенная, необоснованная дифференциаџия оплаты труда и распространенность неправовых практик $в$ трудовой сфере. Глубокий анализ позволил обосновать, что изменение секторальных соотношений занятости в Украине обусловлено не только экономическими факторами, но и интеграционными и дезинтеграциинными процессами, что объясняет явления деиндустриализации и дезаграризаџии труда.

Ключевые слова: занятость, неформальная занятость, номинальная заработная плата, отраслевая дифференциация заработной плать, производительность труда, минимальная заработная плата, прожиточный минимум трудоспособного человека, уровень безработииы, пособие по безработице. 